DOE/AN/99286--T4

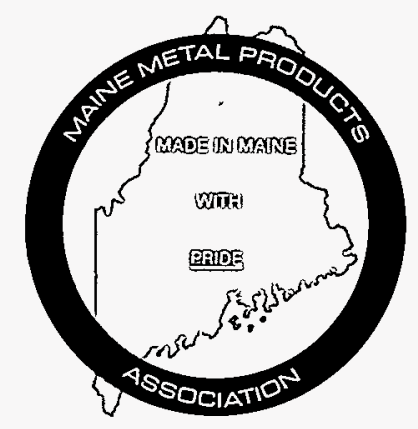

\title{
Environmentally Conscious Manufacturing Project ECM Assessment Guidance Manual
}

November 1994

\section{MASTER}




\section{DISCLAIMER}

\section{Portions of this document may be illegible in electronic image products. Images are produced from the best available original document.}




\section{Acknowledgments}

This manual was developed based on concepts and information presented at the October, 1994, ECM Project Assessment Team Training workshop. The workshop was taught by:

Robert B. Pojasek, PhD.

Cambridge Environmental, Inc.

58 Charles Street

Cambridge, MA 02141

This document was prepared by the Maine Metal Products Association (MMPA) Environmentally Conscious Manufacturing (ECM) Project. The ECM Project is supported in part through Grant No. DE-FG04-94AL99286 form the Advanced Research Project Agency and the U. S. Dept. of Energy through the Defense Conversion and Technology Reinvestment Project. MMPA and the ECM Project are solely responsible for the contents.

\section{DISCLAIMER}

This report was prepared as an account of work sponsored by an agency of the United States Government. Neither the United States Government nor any agency thereof, nor any of their employees, makes any warranty, express or implied, or assumes any legal liability or responsibility for the accuracy, completeness, or usefulness of any information, apparatus, product, or process disclosed, or represents that its use would not infringe privately owned rights. Reference herein to any specific commercial product, process, or service by trade name, trademark, manufacturer, or otherwise does not necessarily constitute or imply its endorsement, recommendation, or favoring by the United States Government or any agency thereof. The views and opinions of authors expressed herein do not necessarily state or reflect those of the United States Government or any agency thereof. 


\section{Introduction}

The purpose of this document is to provide a summary of the basic tools that will be used in conducting assessments under the ECM Project assessment program. Environmentally conscious manufacturing can cover a wide range of issues including:

- finding safer alternatives to toxic materials;

- changing processes to become more efficient;

- environmental costs and regulatory compliance;

- waste reduction;

- energy conservation;

- product packaging; and

- product re-use and recycling.

The assessments performed as part of this program will try to identify opportunities to implement technologies/actions that will promote the types of results listed above. The general methodology, or sequence of events, that will be used in conducting assessments is as follows:

1. Form Assessment Team

2. Map Process

- Process Flow Diagram

- Materials Accounting

3. Identify Opportunities

- Activity-based Costing

- Pareto Analysis

4. Identify and Evaluate ECM/Pollution Prevention Alternatives

- Root Cause Analysis

- Brainstorming

- Alternative Screening

5. Implement Alternatives

6. Monitor Progress

All of the assessment steps listed above are addressed in this document except Forming the Assessment team. For the purposes of this document, it is assumed that the Assessment team has already been formed.

All of the assessment tools discussed in this document are well known, widely used process analysis or quality improvement tools which have been adapted for use in evaluating opportunities for ECM/pollution prevention. The discussion of the tools presented herein is not intended to be comprehensive or complete. A list of references which contain detailed information on the derivation and use of these and other assessment tools is included at the end of this document. 


\section{Overview of ECM Assessment Process}

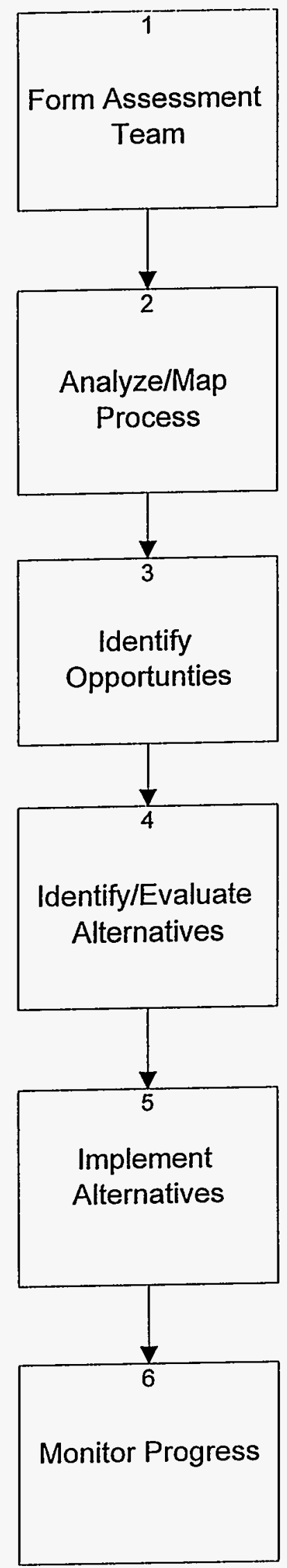

Tools

Process Flow Diagram

Materials Accounting

Activity-Based Costing

Pareto Analysis

Cause and Effect Diagram

Brainstorming

Alternative Screening

Detailed Costing

Pilot Studies

Engineering Design

Recordkeeping

Analysis

Databases 


\section{Process Analysis}

Process analysis is the first and most important step in conducting an ECM assessment. The purpose of process analysis is to identify, define, and outline the process that you want to assess and determine how materials move through this process. Tools for accomplishing this include process mapping and materials accounting.

\section{A. Process Mapping}

Process mapping is an essential first step in trying to understand any activity, whether it be a manufacturing process or an ordinary daily activity. Process mapping consists of drawing a process map or process flow diagram (PFD), which is simply a schematic depiction for defining, refining, and documenting a process. Unit operations or process steps are arranged in the process map to relate functions of the process to which it relates. The process map tells nothing about the physical layout of the operation or facility. In constructing the process map, boxes are generally used to depict the series of process steps (unit operations) which the input materials must pass in the course of transformation to a product. Lines are generally used to represent movement of materials from one process step to another or the time sequence of functions.

One of the difficulties of process mapping is defining the boundaries of the process that you will map. If you do not define and limit the boundaries, the map will become too complicated and will not help you understand the process. To ensure that you are able to define a managable area to map, follow thes steps :

- First, list all of the major processes, or product lines, that occur at the facility.

- Then, pick one of the product lines to focus on first, and identify the major process steps/unit operations involved in running this process/making this product.

- Identify the first and last process steps in the process that you selected and draw your map boundaries around these.

- Fill in the other major process steps/unit operations between the first and last steps.

After completing this initial process map, you may decide that you want to focus on one piece of this larger process, which has several subprocesses, in detail. For example, if you are assessing a facility where furniture is made, you may initially draw the boundaries of your process map around the metal chair manufacturing area. In this area, metal parts are cut and bent, degreased, painted, and assembled. You draw a map around these process steps, but then take a more detailed look at the process and realize that the painting operation acutally includes several subprocesses including a phosphate wash, rinse, prime coat, final coat, and drying. You then decide to limit the boundaries to the painting process and generate a more detailed, focused process map as illustrated on the following page.

\section{B. Materials Accounting}

Materials accounting involves identifying and quantifying the types of materials that are input into and lost from a process. Some people call this activity a "materials balance". The difference between a materials balance and materials accounting is that the former is designed to 


\section{Example Process Flow Diagram}

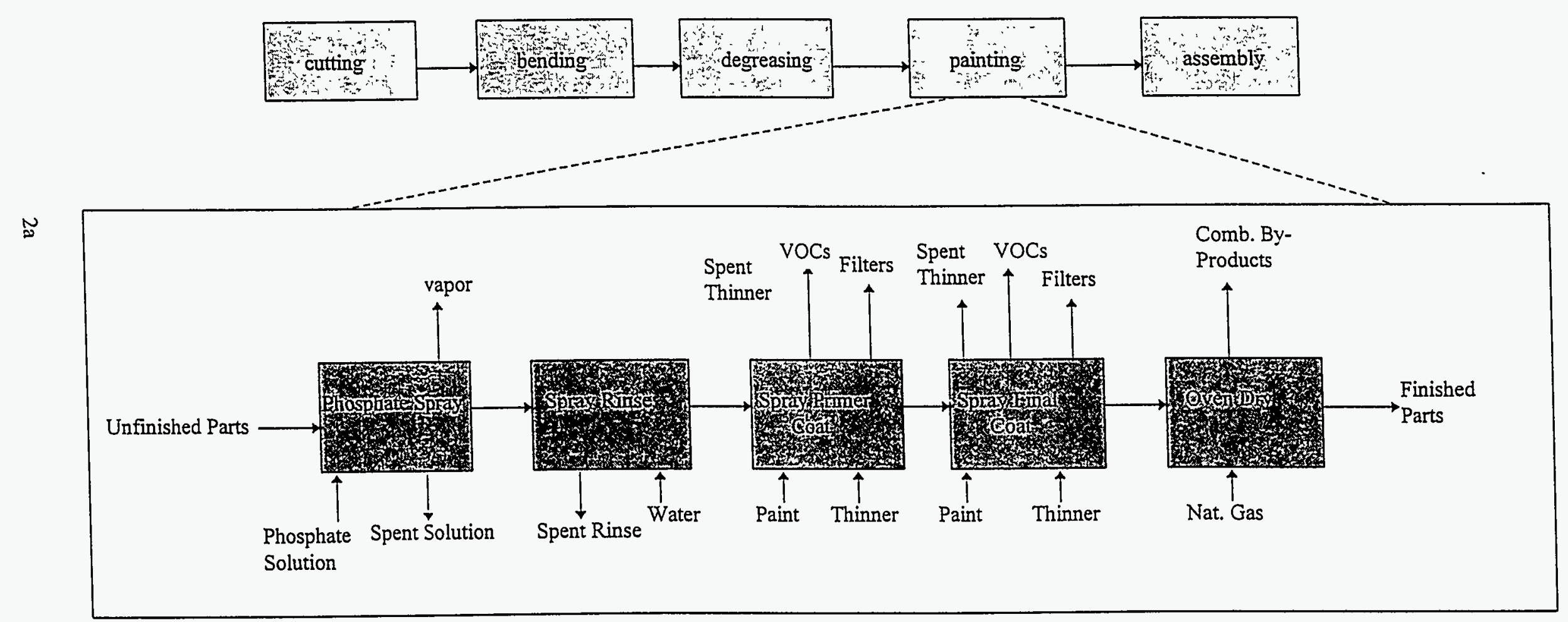


quantify inputs and outputs very precisely, whereas the latter is much less precise. The purpose f materials accounting is to develop a good sense of where the major inefficiencies/losses in a process are so that they be addressed by ECM/pollution prevention. Therefore, it is not necessary to account for every pound or gallon of material; a rough estimate $(+/-30 \%)$ is generally sufficient. Some possible sources of information for these cost estimates include, in order of priority,: (a) interview of production line workers or supervisors; (b) simple calculations (e.g. $2 \times 2 \times 4$ tank emptied daily $=120$ gall/day); and (c) readily available written information such as process operating data, maintenance logs, SARA 313 reports, annual waste reports, etc.

A general procedure for conducting materials accounting is as follows:

- For each process step in your process map, schematically illustrate where material inputs and losses are occurring;

- make a rough estimate of material inputs and losses ( solid or liquid wastes, air emissions or other by-products, spills, leaks or accidental losses) from each process step/unit operation.

- Tabulate material inputs and losses as illustrated:

\section{Example Materials Accounting Table}

\begin{tabular}{|c|c|c|c|c|}
\hline Process Step & Materials Used & Amount/month & Materials Lost & Amount/month \\
\hline Phosphate Spray & $\begin{array}{l}\text { Phosphate Chemical } \\
\text { Water }\end{array}$ & $\begin{array}{l}10 \mathrm{lb} . \\
500 \text { gallons }\end{array}$ & $\begin{array}{l}\text { Dirty Solution } \\
\text { Water Vapor }\end{array}$ & $\begin{array}{l}450 \text { gallons } \\
50 \text { gallons }\end{array}$ \\
\hline Phosphate Rinse & Water & 500 gallons & $\begin{array}{l}\text { Dirty Rinse Solution } \\
\text { Water Vapor }\end{array}$ & $\begin{array}{l}450 \text { gallons } \\
50 \text { gallons }\end{array}$ \\
\hline Primer Spray & $\begin{array}{l}\text { Paint } \\
\text { Thinner }\end{array}$ & $\begin{array}{l}50 \text { gallons } \\
10 \text { gallons }\end{array}$ & $\begin{array}{l}\text { Paint fillers } \\
\text { waste thinner } \\
\text { VOCs }\end{array}$ & $\begin{array}{l}100 \mathrm{lb} . \\
15 \text { gallons } \\
15 \text { gallons }\end{array}$ \\
\hline Final Coat & $\begin{array}{l}\text { Paint } \\
\text { Thinner }\end{array}$ & $\begin{array}{l}40 \text { gallons } \\
10 \text { gallons }\end{array}$ & $\begin{array}{l}\text { Paint filters } \\
\text { waste thinner } \\
\text { VOCs }\end{array}$ & $\begin{array}{l}100 \mathrm{lb} . \\
10 \text { gallons } \\
15 \text { gallons }\end{array}$ \\
\hline Dry & $\begin{array}{l}\text { Natural Gas } \\
\text { Parts with wets paint }\end{array}$ & $\begin{array}{l}1,000,000 \text { cubic feet } \\
1,000 \text { parts }\end{array}$ & $\begin{array}{l}\text { Combustion Product } \\
\text { VOCs }\end{array}$ & $\begin{array}{l}\text { estimate if needed } \\
5 \text { gallons }\end{array}$ \\
\hline
\end{tabular}

\section{Identify ECM/Pollution Prevention Opportunities}

In conducting an ECM/pollution prevention assessment, one of the main goals to ensure success is to focus the assessment on those waste streams/losses (solid or hazardous waste, wastewater, air emissions, spills, leaks or accidental losses) that are the most expensive to handle and therefore whose reduction/elimination will be most beneficial. It is for these waste streams that pollution prevention opportunities are greatest. Two of the tools for 
identifying these waste streams/losses include: (a) activity-based costing; and (b) Pareto Analysis.

\section{A. Activity-Based Costing}

Activity-based costing is a useful method for determining where fruitful opportunities for pollution prevention exist in a manufacturing process. There are a number of activities that that must be in-place to ensure smooth operation of a manufacturing process, including such general items as labor, materials, and equipment. The costs associated with these activities can be termed activity-based costs (ABCs). In evaluating pollution prevention opportunities, the most useful activities to look are Environmental, Health, \& Safety (EHS)type activities such as those listed in the table below. By estimating activity-based costs (ABCs), one can determine what portion of general overhead costs are associated with specific EHS activities and waste streams. Examples of some of EHS activities include:

\begin{tabular}{|l|l|l|l|}
\hline $\begin{array}{l}\text { LABOR } \\
\text { (indirect labor) }\end{array}$ & $\begin{array}{l}\text { MATERIALS } \\
\text { (non-production) }\end{array}$ & $\begin{array}{l}\text { EQUIPMENT } \\
\text { (non-production) }\end{array}$ & OTHER \\
\hline production re-work & pollution control materials & & depreciation \\
\hline material handling & solvents & cleaning/degreasing equip. & waste disposal \\
\hline inspection & process water & material handling machinery & insurance \\
\hline recordkeeping & cleaning water & wastewater treatment equip. & utilities \\
\hline manifesting & maintenance supplies & air pollution control equip. & training \\
\hline labeling & training materials & & taxes \\
\hline training & safety supplies & waste storage equipment & monitoring fees \\
\hline $\begin{array}{l}\text { environmental } \\
\text { reporting/permitting }\end{array}$ & & maintenance equipment & reporting fees \\
\hline & & waste treatment equipment & consultant fees \\
\hline
\end{tabular}

The activities listed above are only some examples; different activities may be more appropriate for your process. When calculating $\mathrm{ABCs}$ for the purpose of identifying pollution prevention opportunities, it is not necessary to calculate the numbers with absolute precision; two significant figures and a precision of $+/-30$ percent is generally sufficient. A general procedure to follow to calculate these costs is as follows:

- Identify the major activities in which EHS costs are expended such as permits, monitoring, waste disposal, waste treatment, etc.

- Make a rough estimate of the total cost associated with each activity (this estimate does not have to be precise, within $+/-30$ percent is good)

- Then estimate the percentage of the $\mathrm{ABCs}$ attributable to each of the process waste streams/losses

- Tabulate the ABCs for each waste stream/loss as illustrated below. 
Example Activity-Based Cost/Losses Matrix

\begin{tabular}{|c|c|c|c|c|c|c|}
\hline $\begin{array}{l}\text { Losses } \\
\text { ABC Costs }\end{array}$ & Total Costs & \begin{tabular}{|l} 
Spent Wash \\
Solution
\end{tabular} & $\begin{array}{l}\text { Spent Rinse } \\
\text { Solution }\end{array}$ & $\begin{array}{l}\text { Paint Booth } \\
\text { VOC } \\
\text { Emissions }\end{array}$ & $\begin{array}{l}\text { Waste Liquid } \\
\text { Paint/Thinner }\end{array}$ & $\begin{array}{l}\text { Waste } \\
\text { Paint Solids } \\
\text { (filters, etc.) }\end{array}$ \\
\hline Permitting & 2,500 & 500 & 500 & 1,500 & & \\
\hline $\begin{array}{l}\text { Non-Hazardous } \\
\text { Waste Disposal }\end{array}$ & 5,000 & 500 & 500 & & & 4,000 \\
\hline $\begin{array}{l}\text { Air Pollution } \\
\text { Control }\end{array}$ & 90,000 & & & 90,000 & & \\
\hline $\begin{array}{l}\text { Hazardous } \\
\text { Waste Disposal }\end{array}$ & 10,000 & & & & 10,000 & \\
\hline $\begin{array}{l}\text { Wastewater } \\
\text { Treatment }\end{array}$ & 3,000 & 2,000 & 1,000 & & & \\
\hline Monitoring & 1,200 & 500 & 500 & 200 & & \\
\hline Utilities & 500 & 100 & 100 & 300 & & \\
\hline Process Water & 600 & 300 & 300 & & & \\
\hline Total Costs & 112,800 & 3,900 & 2,900 & 92,000 & 10,000 & 4,000 \\
\hline
\end{tabular}

\section{B. Pareto Analysis}

Once the $A B C s$ have been estimated, a Pareto Chart is prepared to graphically illustrate where the majority of the costs are expended, thus the place to focus your ECM/P2 efforts. The concept behind the Pareto Chart is the $80 / 20$ rule which says that 80 percent of the problem comes from 20 percent of the causes.

In the case of our analysis, 80 percent of the activity-based costs should be associated with 20 percent of the waste streams/losses. Basically, a Pareto Chart rank orders the causes of a particular problem. It does this by arranging data in bar chart form in descending order from left to right, where the left axis depicts actual data and the right axis represents a percentage of the total. The causes of the problem, the losses/waste streams, are listed on the horizontal axis. The basic steps in generating a Pareto Chart include:

1. Select the variable to be placed on the horizontal axis. In our case, this will generally be waste streams, but other variables can be used. The variables selected should be mutually exclusive.

2. Determine the units that you will use to measure each variable, which in our case might be the monthly or annual cost associated with each waste stream. 
3. Create the Pareto Chart (see example below). The horizontal axis should show the waste streams/losses, and the left vertical axis should be the actual value (cost) estimated for each waste stream. The variable with the largest actual value should be placed against the far left vertical axis. The next vertical bar represents the second largest value and should touch the first bar, and so on. The right vertical axis should depict the percentage values of the actual data. The 100 percent mark should be at the same height as the total dollars expended for all losses/waste streams.

4. Typically, $20 \%$ of the losses represent $80 \%$ of the total costs.

An example Pareto chart for the data presented above is illustrated below. This Pareto chart shows that air emissions from the painting process is one area where pollution prevention could result in significant savings. Although the total savings may be less, pollution prevention efforts for the other waste streams would also result in savings and may be easier to achieve. The purpose of the Pareto Chart is to graphically show where major costs to handle waste streams are being spent and where pollution prevention efforts should be focused.

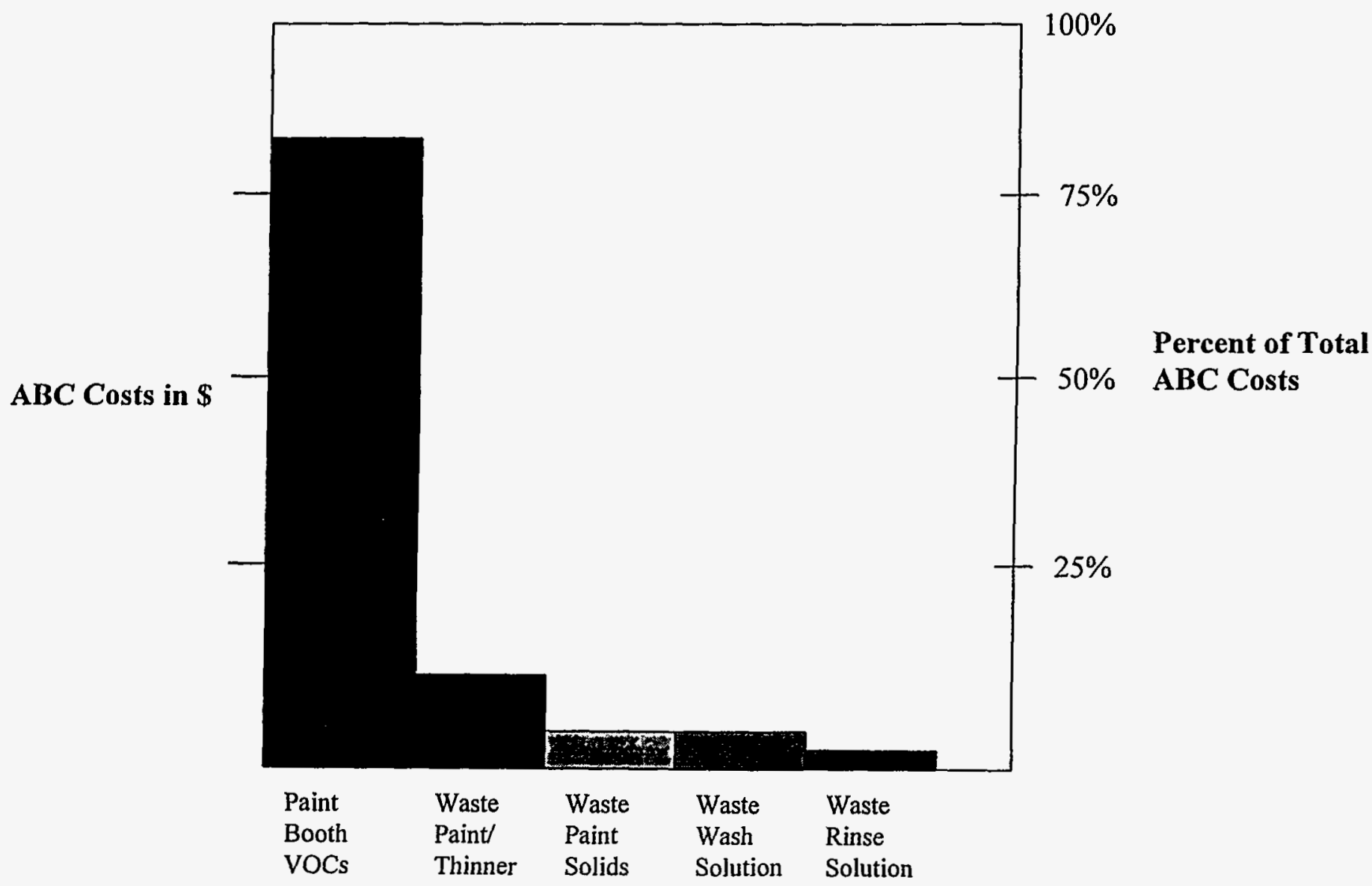

\section{Losses}


The Pareto chart is particularly useful in showing owners/managers where significant savings can be achieved.

\section{Identification of Pollution Prevention Alternatives}

Identification of alternatives to solve a certain problem generally requires several steps. It is first necessary to understand/identify the causes of the problem. Then, it is necessary to come up with a large number of potential solutions to the problem. Then, it is necessary to reduce the large number of potential alternatives to those that are really worth pursuing. The three tools for doing this include:

- Root Cause Analysis

- Brainstorming/brainwriting

- Alternative Screening

\section{A. Root cause Analysis}

In ECM and pollution prevention, a root cause analysis is generally performed to understand why the unwanted waste stream is being generated or why the toxic or hazardous material is being used. There are a number of techniques for determining the root cause of a problem. Two of the techniques that we will use in the ECM Project are: (i) asking "dumb questions"; and (ii) constructing cause and effect (fishbone) diagrams.

\section{Dumb Questions*}

"Dumb" questions are really just questions designed to find out why something is the way that it is. These include questions that someone who is not familiar with the process would ask such as: "Why do need to clean that part?". In fact, they are not really dumb questions, they just seem dumb to someone that has beome accustomed to the way something is done and has stopped asking why it is done that way. One suggested method of ensuring that the "dumb" questions are asked and getting to the root of a problem is to ask why something is occurring, and then ask why? four more times. For example:

1. Why did the neighbors complain of odors? Because chemical are emitted from our paint booth stack.

2. Why are chemicals emitted from the paint booth? Because some of the chemicals in the paint do not end up on the part, but are emitted through the vent instead.

3. Why do some of the chemicals not attach to the part? With the spray gun, it is hard to control where all of the paint goes.

4. Why is the spray gun hard to control? It generates a wide stream of spray that can not be directed specifically at the part.

5. Why don't we have a spray gun that can be controlled?

This is the type of spray gun that we've always used.

* see, references, Thompson, Charles, WHAT A GREAT IDEA 


\section{Cause and Effect Diagrams}

Cause and effect diagrams are a visual tool that is useful for finding the root cause of a problem, which is termed the effect. The procedure for generating a cause and effect diagram is as follows (see example below):

1. Write the problem that you are trying to solve in a box at the right hand side of the page.

2. Then, define major categories of possible causes of the problem. Commonly used categories are Manpower (personnel), Methods, Machines/tools, Materials, surroundings (place).

3. Place these major categories in boxes connected to the fishbone.

4. Write the casuses of the problem on the branch of the fishbone under the appropriate category.

\section{Example Cause and Effect Diagram}

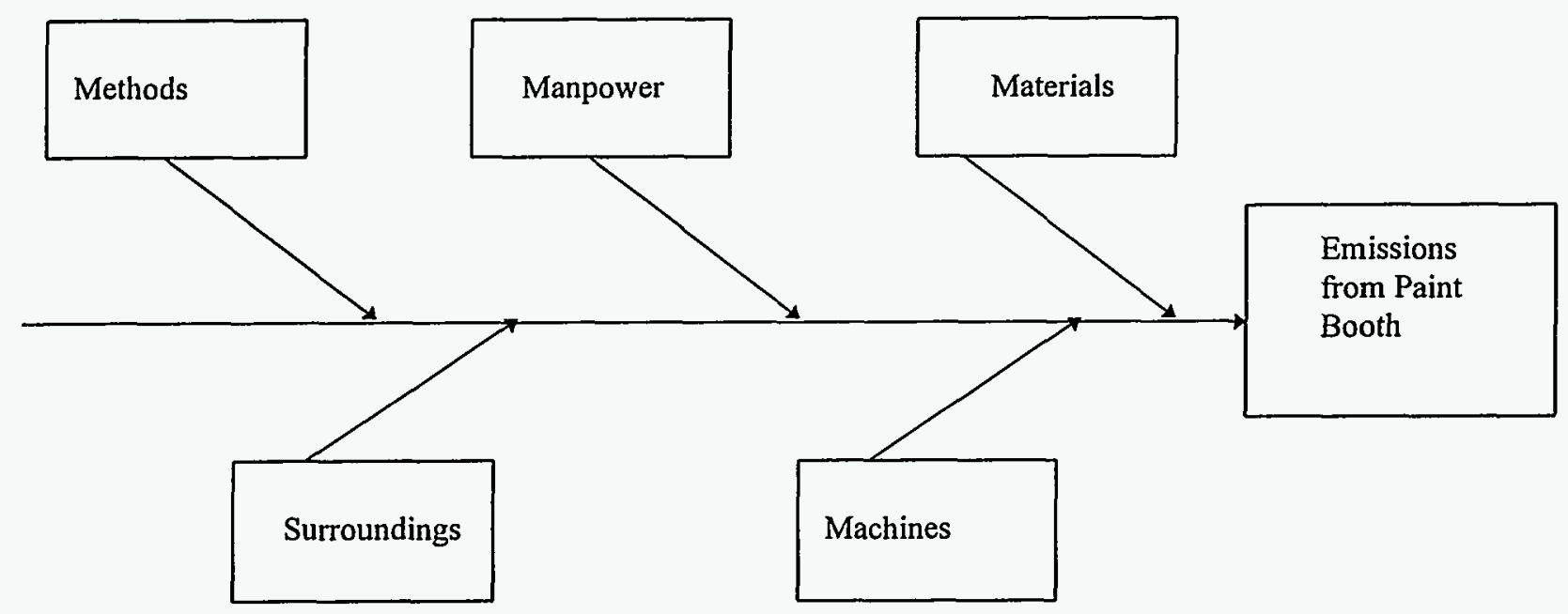

The causes identified using the cause and effect diagram help to identify potential pollution prevention alternatives. For example, if oily wastewater is identified as a problem, and one of the causes is lack of attention to machine maintenance, an alternative would be to develop a better machine maintenance program. Another example would be if hazardous waste from a cleaning operation is the problem, and the cause of the problem is that the cleaning solvent is a hazardous material, a solution would be to replace the existing solvent with a non-hazardous material. 


\section{B. Brainstorming/brainwriting}

Other specific methods of identifying pollution prevention alternatives include: brainstorming (verbal or written), storyboarding, and mind mapping. The first method, brainstorming, is probably the most well known method to most people, and it will probably the method that will be used in our assessments.

Brainstorming is a useful technique for generating a number of ideas or alternatives to solve a given problem. Sometimes, in verbal brainstorming, the less outspoken assessment team members may for various reasons not be able to voice their ideas. Written brainstorming can be used to avoid this problem. In brainwriting, each assessment team member is given a sheet with a number of boxes on it. Each person writes an idea (pollution prevention alternative) in a box and then passes the sheet on to another person. If appropriate, comments can also be added to the alternatives written in each box. The sheets are passed back and forth until a number of the boxes on each sheet have been filled out. Prior to starting the brainstorming session, set a time limit of 10-15 minutes. This will help encourage spontaneity, and prevent the session from dragging on too long.

\section{C.. $\quad$ Screen Alternatives}

Once a list of alternatives has been developed, first identify and eliminate duplicate alternatives. Then, screen the alternatives to arrive at a manageable number to consider as serious candidates for implementation. Screening should be done with respect to relevant criteria, some examples of which are listed below.

\begin{tabular}{|c|c|c|}
\hline Effectiveness & Implementability & Cost \\
\hline - Fits Company Goals & $\begin{array}{l}\text { - Well-documented Cases } \\
\text { Available }\end{array}$ & - Lessens Liability Exposure \\
\hline - Diminsh Materials Use & - Variety of Vendors Available & - Matching Funds Available \\
\hline $\begin{array}{l}\text { Increase Production } \\
\text { Efficiency }\end{array}$ & $\begin{array}{l}\text { Good Operating Practice } \\
\text { Available }\end{array}$ & - Savings on Treatment/Disposal Costs \\
\hline - Reduce Safety Hazards & - Low Risk of Media Transfer & - Expedient Payback Potential \\
\hline $\begin{array}{l}\text { Minimizes Regulatory } \\
\text { Compliance Needs }\end{array}$ & - $\quad$ No Permits Required & - Low O\&M Costs \\
\hline - Achieves Waste Reduction & - Management Support & - Low Capital Costs \\
\hline
\end{tabular}

A number of methods can be used to screen the alternatives to determine which alternatives are worth considering in detail. Some EPA and DOE people use a "weighted sums" method in which a weight is assigned to each criterion based on its importance. Once the alernative is rated with respect to a certain criterion, the weight factor is multiplied by the rating to reflect the overall importance of that criterion. The sum of all ratings yields the overall score for the alternative.

A simpler method to use, particularly in the initial level of screening of pollution prevention alternatives, is to assign a weight of " 1 " to all criteria. A rating of $-1,0$, or +1 is then assigned according to how well an alternative satisfies the criterion. An example screening matrix is presented on the following page. This example illustrates a simplified screening method that can be used. 
In the example, the powder coating alternative is the highest rated alternative and would be the most seriously considered alternative for implementation. Conversely, contracting out painting services and water-based painting are the lowest rated alternatives and would probably be eliminated from further consideration. The other two alternatives, changing spray guns and improved operating practices may be worth implementing in the short term prior to getting the powder coating system on line. Therefore, when screening alternatives you should use the scoring technique as a way to evaluate each alternative, but you should not necessarily eliminate all but the highest scoring alternative. Some of the alternatives may be short-term, temporary solution and others may be the long-term, permanent solution. One way of supplementing the numerical ranking technique to ensure that alternatives are considered fairly is to list the pros and cons of each alternative as shown on the following page. 
Example Alternatives Screening Matrix

\begin{tabular}{|c|c|c|c|c|c|}
\hline Criteria & $\begin{array}{l}\text { More Efficient } \\
\text { Spray liquipment }\end{array}$ & $\begin{array}{l}\text { Improve Operating } \\
\text { Procedures }\end{array}$ & $\begin{array}{l}\text { Change to } \\
\text { Powter Paiuts }\end{array}$ & $\begin{array}{l}\text { Cliange to Water- } \\
\text { liased Paints }\end{array}$ & $\begin{array}{l}\text { Contract out } \\
\text { Painting }\end{array}$ \\
\hline Fits Company Goals & $T$ & I & 1 & 1 & -1 \\
\hline $\begin{array}{l}\text { Reduces Toxic Materials } \\
\text { Use }\end{array}$ & $T$ & 0 & $T$ & 1 & 1 \\
\hline Reduces Safety Hazards & $\overline{0}$ & $\overline{0}$ & 1 & 1 & 1 \\
\hline $\begin{array}{l}\text { Increases Production } \\
\text { Efficiency }\end{array}$ & 0 & -1 & I & 0 & -1 \\
\hline $\begin{array}{l}\text { Achieves Waste } \\
\text { Reduction }\end{array}$ & 1 & 1 & 1 & 1 & 1 \\
\hline $\begin{array}{l}\text { Well-documented Cases } \\
\text { Available }\end{array}$ & I & 1 & 1 & 0 & 0 \\
\hline $\begin{array}{l}\text { Variety of Vendors } \\
\text { Available }\end{array}$ & $\overline{1}$ & $T$ & 1 & 1 & 1 \\
\hline $\begin{array}{l}\text { Eliminate Need for } \\
\text { Permit }\end{array}$ & -1 & -1 & 1 & $\overline{1}$ & 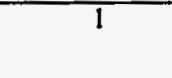 \\
\hline $\begin{array}{l}\text { Reduced Trealment } \\
\text { Disposal Costs }\end{array}$ & 0 & 0 & 1 & 0 & 1 \\
\hline Low Capital Cost & 1 & 1 & -1 & -1 & 1 \\
\hline Low O\&M Cost & 1 & I & $\overline{0}$ & 0 & -1 \\
\hline Totals & 6 & 7 & $\overline{8}$ & $\overline{5}$ & 4 \\
\hline
\end{tabular}

\section{Pros and Cons Matrix}

\begin{tabular}{|l|l|l|}
\hline Alternative & Pros & Cons \\
\hline More Efficient Spray Equipment & $\begin{array}{l}\text { Relatively inexpensive } \\
\text { Will reduce paint use }\end{array}$ & $\begin{array}{l}\text { May reduce production efficiency, finish quality } \\
\text { Permit still required }\end{array}$ \\
\hline Improved Operating Procedures & Very inexpensive, easy to implement & Permit still required \\
\hline Powder Painis & $\begin{array}{l}\text { Eliminate Need for Permit } \\
\text { Eliminate Haz. Waste }\end{array}$ & $\begin{array}{l}\text { Very Costly } \\
\text { Long time to implement }\end{array}$ \\
\hline Water-based paints & $\begin{array}{l}\text { Eliminate Need for Permit } \\
\text { Eliminate Ilaz. waste }\end{array}$ & $\begin{array}{l}\text { Increase wastewater } \\
\text { Expensive }\end{array}$ \\
\hline Contract out Painting & $\begin{array}{l}\text { Eliminate Need for Permit } \\
\text { Eliminate Haz. Waste }\end{array}$ & $\begin{array}{l}\text { Lose direct control } \\
\text { possible reduced production } \\
\text { Relatively expensive }\end{array}$ \\
\hline
\end{tabular}




\section{Implementation}

In order to ensure that there is some follow-up with the pollution prevention alternatives that were identified, an implementation plan should be prepared. The implementation plan should outline the activities that need to take place to reach the desired goal of a reduction in waste, use of toxic materials, etc. The implementation plan should not be limited to a date by which the final solution will be in-place. It should include certain milestones along the way and a schedule for monitoring progress. An example implementation plan may look like this:

\begin{tabular}{|c|c|c|c|}
\hline Date & Activity & Completed & Comments \\
\hline $2 / 15 / 94$ & $\begin{array}{l}\text { Begin tracking daily paint } \\
\text { usage }\end{array}$ & & \\
\hline $2 / 15-2 / 28$ & $\begin{array}{l}\text { Evaluate Economics of } \\
\text { Powder System in Detail }\end{array}$ & & \\
\hline $2 / 15-2 / 28$ & $\begin{array}{l}\text { Install HVLP Guns on Trial } \\
\text { Basis }\end{array}$ & & \\
\hline $3 / 1 / 94$ & $\begin{array}{l}\text { Train operators on improved } \\
\text { operating procedures }\end{array}$ & & \\
\hline $5 / 15$ & $\begin{array}{l}\text { Evaluate Paint Usage Data } \\
\text { since } 3 / 1\end{array}$ & & \\
\hline $5 / 15-8 / 1$ & $\begin{array}{l}\text { Evaluate/Select Powder } \\
\text { Coating Suppliers }\end{array}$ & & \\
\hline $8 / 1-8 / 30$ & Design/Install System & & $\begin{array}{l}\text { This may not be done if significant reductions } \\
\text { have been achieved through initial actions }\end{array}$ \\
\hline $12 / 1$ & $\begin{array}{l}\text { Evaluate Powder System } \\
\text { Performance }\end{array}$ & & \\
\hline
\end{tabular}

In addition to an implementation plan, you should make sure that the assessment team meets regularly to evaluate ongoing opportunities for ECM/Pollution Prevention, i.e. Continuous Improvement.

\section{Monitoring Progress}

Monitoring progress can be done in several ways depending on the type of activity that is being monitored. One way of monitoring progress is to look at the production efficiency of a process: 


\section{Efficiency $=$ Materials Used - Materials Lost $\quad \times 100 \%$ Materials Used}

This method works if you are evaluating a process in which you have kept the same materials, but have changed the process to reduce losses. An example would be changing to a paint spray gun that reduces the amount of overspray. If you compare materials used vs. materials lost before and after the change, you will get a sense of the increase of efficiency. However, if the alternative involves a change from a more toxic to a less toxic material, this method will not work. The process losses may be equal in terms of volume or weight, but their environmental impact will be reduced. Therefore, other techniques for monitoring progress must be used. These techniques may involve looking at the change in:

1. toxicity or hazard of the waste streams generated using EPA lists of priority chemicals, such as EPA TRI Chemical (SARA 313) list, EPA's 33/50 list, or RCRA hazardous waste criteria;

2. the overhead costs associated with handling the materials or waste streams that you are trying to reduce (as identified in activity-based costing);

3. other measures, such as energy, water or fuel usage.

The selection of one of the above methods or another method will have to be based on the specific alternative that you have implemented. The important part of monitoring is that it be performed on a regular basis, annually, semi-annually, quarterly, or whatever time period makes sense. 


\section{RUITIRTNCAS}

Deborah Hartington-Mackin, THE TEAM BUILDING TOOL KIT. American Management Associaztlon, New York, NY, 1994. ISBN 0-8144-7826-3.

Peter R. Scholtes. THE TEAM HANDBOOK. Jolner Assoclates, Madison, WI , 1988. ISBN $0-9622266-08$.

Edward deBono, DBBONO's THINKING COURSE. Facts on File, New York, NY, 1985. ISBN 0-8160-1895.

Don Koberg and $J i m$ Bagna 11 , THE UNIVBRSAL TRAVBLBR, W $1111 \mathrm{am}$ Kaufmann Inc., Los Altos, CA, 1976. ISBN 0-913232-05-X.

Michael Brassard, THE MEMORY JOGGHR PLUS, Goal/QPC, Methuen, MA, 1989. ISBN 1-879364-02-6.

Mary Mal ton, THE DEMING MANAGEMENT METHOD, Perlgee Books, New York, NY 1986. ISBN 0-399-550-3.

Roger von oech, A KICK IN THE SEAT OF THE PANTS, Harper \& Row Publishers, New York, NY, 1980. ISBN 0-06-096024-8.

Charles Thompson, WHAT A GRENT IDEA, Harper Perennial, New York, NY, 1992. ISBN 0-06-096901-6.

Joyce Wycoff, MINDMAPPING, Berkely Books, New York, NY, 1991. ISBN $0-425-12780-X$.

Thomas G. Gunn, $215 T$ CENTURY MANUFACTURYNG, Harper Collins, New York, NY, 1992. ISBN 0-88730-946-6.

Kaoru I shikawa, GUIDE TO QUALITY CONTROL, QUal1ty Resources, white Plalns, NY, 1968, ISBN 92-833-1036-5.

Rlchard $Y$. Chang and $P$. Kelth Kelly, STEP BY STEP PROBLEM 5OLVING, Richard Chang Assoc, Irvine, CA, 1993. ISBN 1-883553-11-3.

Rlchard $Y$ Chang and Mat thew E. Nledzwleckl, CONTINUOUS IMPROVEMENT Tools ( 2 Volumes), Richard Chang Assoclates, Irvine, CA. ISBN 1883553-02-04.

Harry Costin, READINGS IN TOTAL QUALITY MANAGBMENT, Harcourt Brace \& Co., Fort Worth, TX. ISBN 0-03-097301-5. 
Assessment Tool Templates 


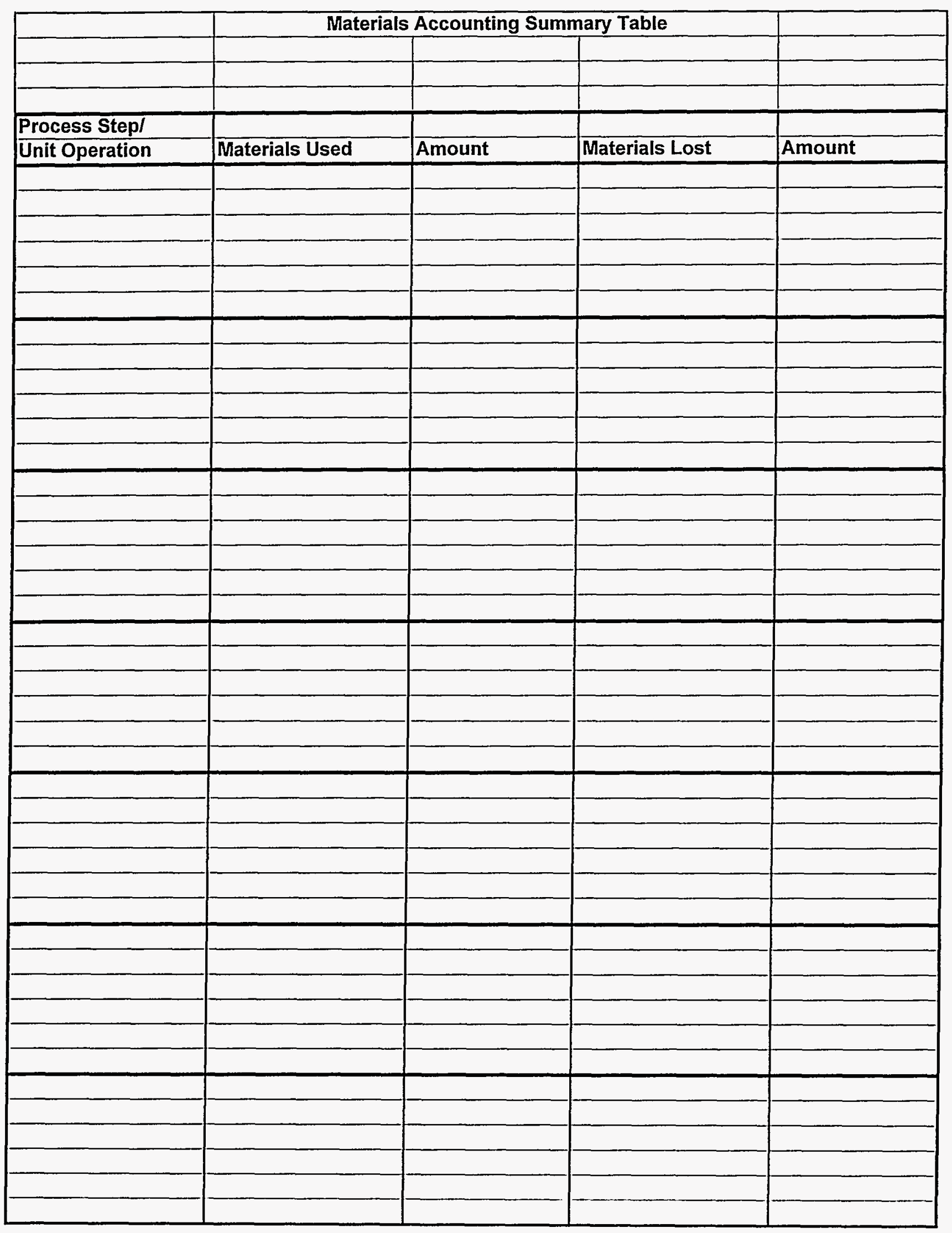




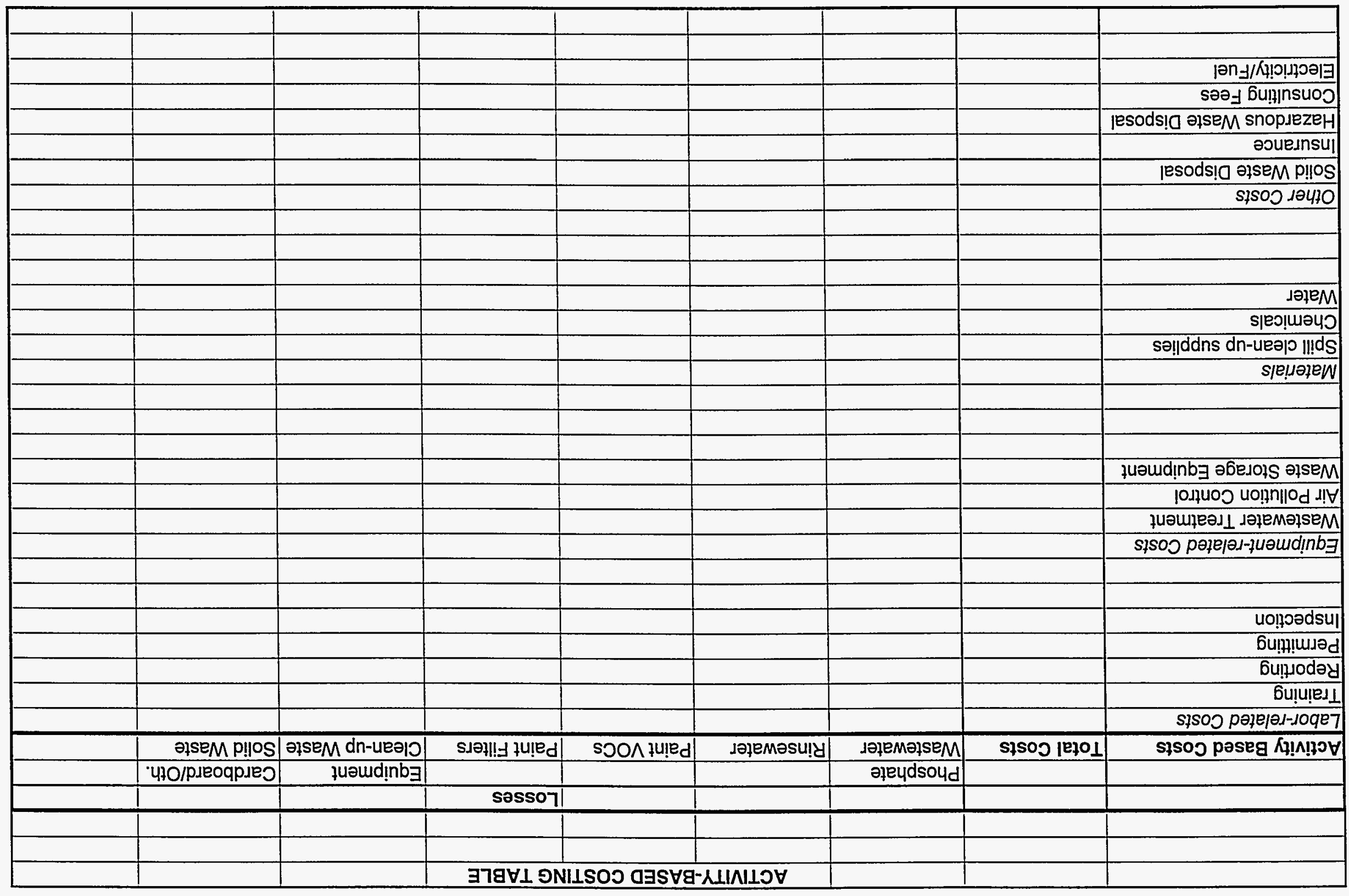




\section{PARETO CHART}

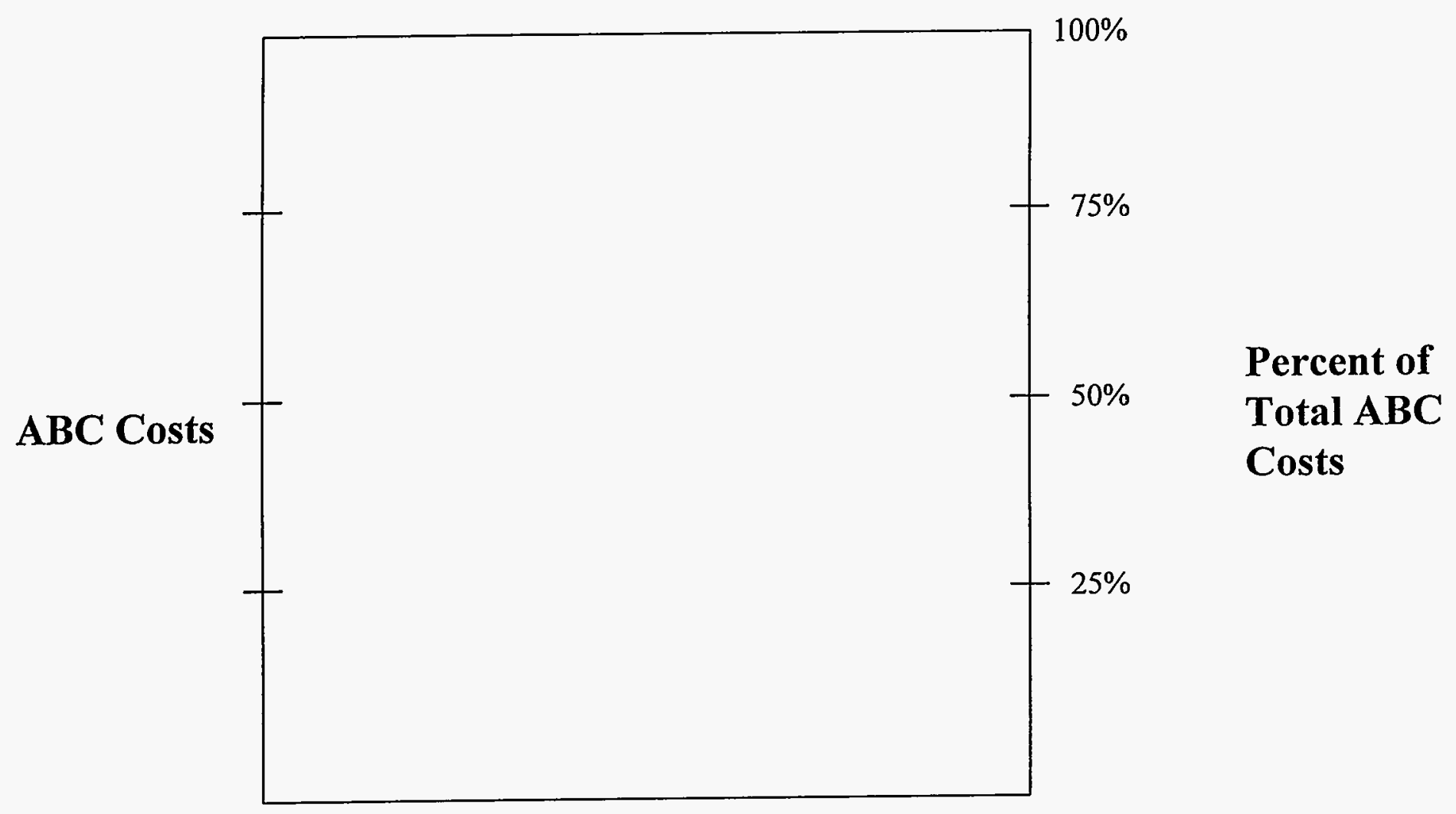

\section{Losses}




\section{Cause and Effect Diagram}

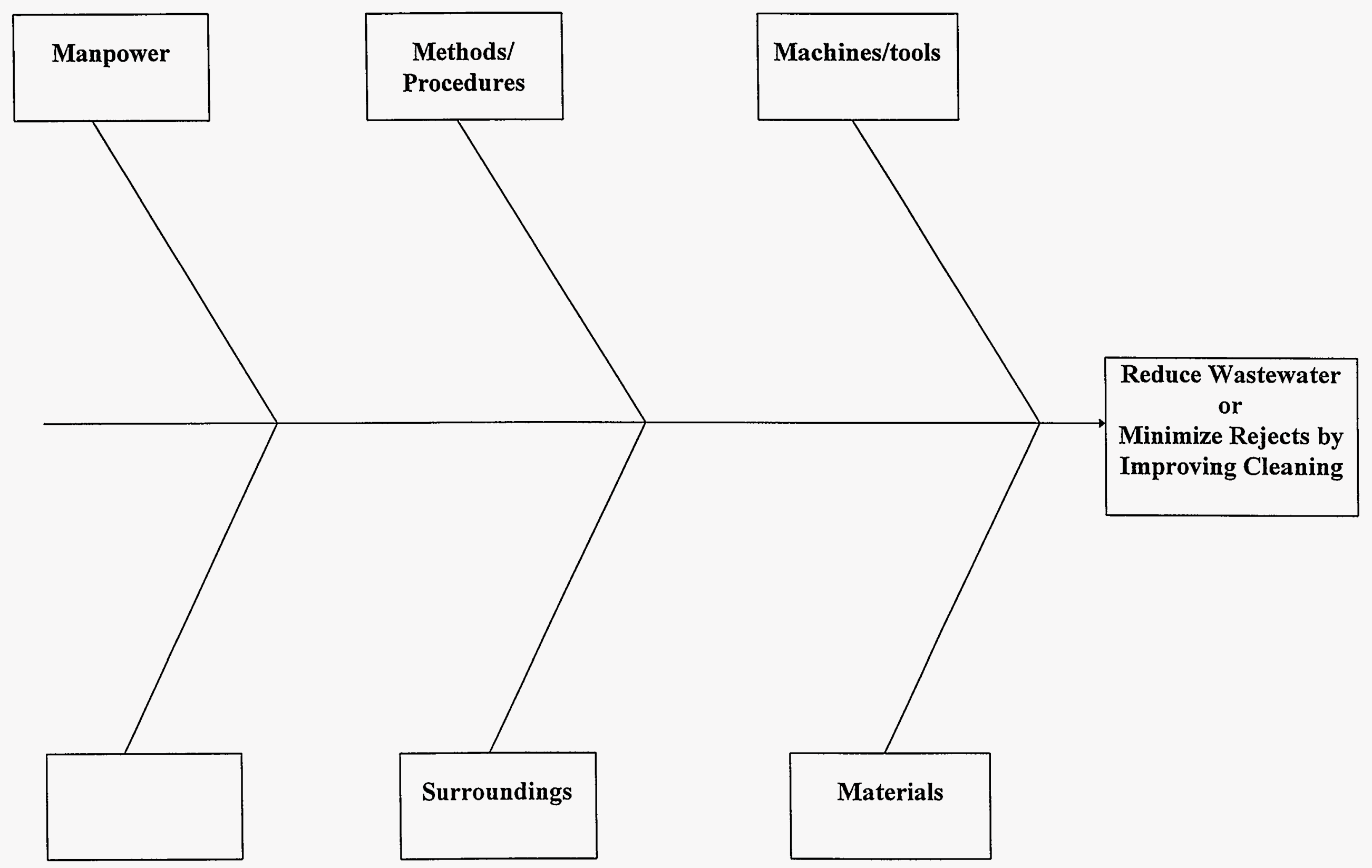


General Process Information Sheet

\begin{tabular}{|l|l|l|}
\hline Major Products & Amount & Comments \\
\hline & & \\
& & \\
& & \\
& & \\
\hline
\end{tabular}

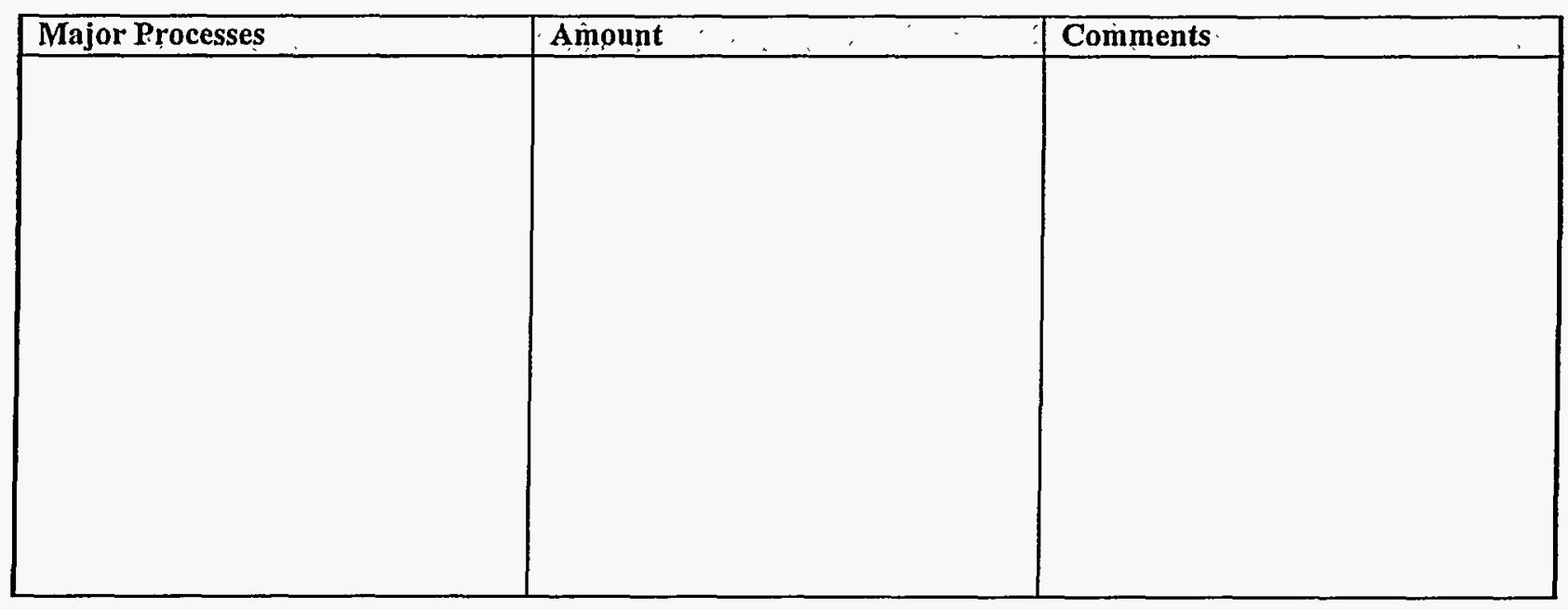

\begin{tabular}{|l|l|l|l|}
\hline Major Raw Materials & Amount & & \\
\hline & & & \\
& & & \\
& & & \\
& & & \\
\end{tabular}




\section{General Process Information Sheet}

\begin{tabular}{|l|l|l|}
\hline Major Solid Waste Streams & Amount & Comments \\
\hline & & \\
& & \\
& & \\
& & \\
\hline
\end{tabular}

\begin{tabular}{|l|l|l|}
\hline Major Air Emissions & Amount & Comments \\
\hline & & \\
& & \\
& & \\
& & \\
\hline
\end{tabular}

\begin{tabular}{|l|l|l|}
\hline Major Wastewater Discharges & Amount & Comments \\
\hline & & \\
& & \\
& & \\
& & \\
\hline
\end{tabular}

